\title{
The Maternity Benefit (Amendment) Bill, 2016: A Critical Analysis
}

\section{Dr Suman Singh ${ }^{\dagger}$}

\section{Abstract}

On 11 August 2016, amending the Maternity Benefit Act, 1961, the new bill, The Maternity Benefit (Amendment) Bill, 2016 was introduced and passed in the Rajya Sabha (or Council of States), the upper house of the Parliament of India. Central aim of this article is to critically review the amendments to the bill regarding geographies of maternity leave and its associated facilities.

Key words: Maternity Benefit Act, 1961, The Maternity Benefit (Amendment) Bill, 2016, maternity leave, childcare, work from home, India.

\footnotetext{
${ }^{\dagger}$ Assistant Professor, Banaras Hindu University Varanasi, Uttar Pradesh, Email: sumansingh.bhu@gmail.com (C) 2016 Singh. This is an Open Access article distributed under the terms of the Creative Commons Attribution License (http://creativecommons.org/licenses/by/2.0), which permits unrestricted use, distribution, and reproduction in any medium, provided the original work is properly cited.
} 


\section{Introduction}

On 11 August 2016, the penultimate day of the Monsoon Session, the Minister for Labour and Employment, Mr. Bandaru Dattatreya introduced and passed The Maternity Benefit (Amendment) Bill, 2016 in the Rajya Sabha (or Council of States), the upper house of the Parliament of India by voice vote. This bill stems from an amendment to the Maternity Benefit Act, 1961. The Act (Act of 53 of 1961 was passed on 12 December 1961) which aimed at regulating the employment of women employees in certain establishments (factory, mines, plantations, shops and other establishments) for stipulated periods before and after the birth of the child by proffering maternity leave and some other related benefits. In other words, the 1961 Act aimed at protecting women's employment during the time of their pregnancies by guaranteeing full paid leave of absence from work to take care of their new-borns. Among other provisions, the new bill mandates 26-week of paid leave for the new mothers in all establishments (including the private sector) as against 12 weeks as per the 1961 Act. After the bill is passed into an Act, India would occupy a fair position in the world's maternity report card. Currently, Scandinavian countries (Denmark, Norway and Sweden) along with other countries like Canada, United Kingdom, Serbia, Croatia, Finland, Greece, etc. offers copious maternal leave policies. For instance, Sweden provides 420 days of maternity leave where the pregnant employee is entitled to $80 \%$ of her wages (Table 1). The key purpose of this review is to critically analyse the geographies connected to The Maternity Benefit (Amendment) Bill, 2016.

The article begins with a brief comparison of parental leaves in different countries across the globe. This follows a scrutiny of the amendments to The Maternity Benefit (Amendment) Bill, 2016.

\section{Provisions of Maternity/Parental Leaves across Nations}

The United States of America, one of the most developed nations of the world and the place where women's rights movement originated under the leadership of Elizabeth Cady Stanton in Seneca Falls in 1848 is a country (Bhattacharyya, 2009) that fails to guarantee paid maternity leave/parental leave to its employees. The 1993 legislation, the Family and Medical Leave Act (FMLA) is perhaps the closest law allowing qualified employees to avail 12week of unpaid but job-protected leave linked to particular family and medical reasons, which of course embraces a pregnant woman's delivery or even adopting a baby/child to care for. The companies employing over 50 employees are bound to follow this legislation. Arguably, in the USA, for paid maternity leave, an expected mother has to rely on her employer. Indeed, out of 196 countries of the world, the maternity policy of the US Government remains the worst. ${ }^{1}$ In a way, the US Government discourages employees/workers to have children. Apparently, maternity leave policy of the USA is similar to the African nations like Liberia and Swaziland and the Oceanian country, Papua New Guinea.

In his election campaigns, which is scheduled for November 2016, Donald J Trump, the Republican Presidential nominee in a meeting in Delaware County, Pennsylvania on 13 September 2016 has promised for a childcare plan-"a childcare tax deductible, up to the average cost in a given family's state, until the age of 13, as well as an expanded rebate of up to $\$ 1,200$ for those families that do not pay income tax and receive earned income tax credit" (Jacobs, 2016). In addition, Trump has promised to "provide six weeks of maternity leave "to any mother with a newborn child whose employer does not provide the benefit"

\footnotetext{
${ }^{1}$ These 10 countries have the best parental leave policies in the world, World Economic Forum. Retrieved from,https://www.weforum.org/agenda/2016/08/these10-countries-have-the-best-parental-leave-policies-inthe-world
} 
by tackling fraud in unemployment insurance" (Jacobs, 2016). However, Trump fails to outline a model as to how his plan would exactly be translated into reality.

On the contrary, European countries (especially Central European countries) proffer very good parental leave benefits to its citizens. In the UK, an expecting British working mother, who is an employee (not a worker and on subject to issuing notification to her employer) is entitled to:

- Statutory Maternity Leave (52weeks-first 26 weeks ordinary maternity leave and additional maternity leave for the next 26 weeks)

- Statutory Maternity Pay \{paid for 39 weeks - for the first 6 weeks, $90 \%$ of average weekly earnings prior to tax deductions and for the next 33 weeks - $90 \%$ or $£ 139.58$ of mean weekly earnings (whichever is lower)\} (see, Table 1)

- paid time off for antenatal care embracing employees' rights

- extra help from the government (such as Child Benefit, Child Tax Credit, Working Tax Credit-this can continue for 39 weeks after a pregnant woman goes on maternity leave and Income Support-may be entitled to even a new mother (subject to qualifying certain regulations of the UK government, who does not work. $)^{2}$

Table 1 illustrates comparative maternity/parental leave provisions of different countries of the world. Few countries have provisions for 'shared parental leave' to take care for the new baby. In countries like the UK, Canada, Sweden and France, homosexual couples and commissioning parents are also entitled to parental leave benefits. In the following section, I critically analyse The Maternity Benefit (Amendment) Bill, 2016.

\footnotetext{
${ }^{2}$ Maternity pay and leave, Gov.uk. Retrieved from, https://www.gov.uk/maternity-pay-leave/overview
}

\section{Maternity Benefits: Will it empower women?}

It was Mrs. Maneka Gandhi's Women and Child Development Ministry, which recommended on raising maternity leave from 12 weeks to 26 weeks so that new mothers can nurture and breast-feed their babies for longer. According to the new bill, an expecting woman can avail leave eight weeks prior to her expected delivery, which was six weeks earlier (as per the 1961 Act). However, a woman, who already is a mother of two or more children, would still be able to avail maternity leave but for a period of 12 weeks, "which cannot be availed before six weeks from the date of the expected delivery." ${ }^{3}$ The other arrangements of the bill are as follows:

\section{Leave for adoptive and commissioning mothers}

Similar to countries like the UK, Canada, Sweden and France, the bill has introduced provisions of leave of 12 weeks for a woman (who adopts a baby legally below three-month old) and for a commissioning mother ("a biological mother who uses her egg to create an embryo implanted in another woman"). ${ }^{4}$ of course, the 12-week period would be computed officially from the day the baby is handed over to the adoptive or commissioning mother. However, it remains unclear, as to if there are any leaves for a mother who adopts a baby who is older than three months. The bill however fails to grant leave of any sort for surrogates and the expectant fathers. Evidence suggests that the surrogates, by renting their wombs, suffer from multiple forms of medical interventions (such as delivery through caesarean sections, hormone infusions, selective reductions, transvaginal ultrasounds, etc.) and emotional pains of being separated from the babies they delivered (Bhattacharyya, 2016a,c; Rudrappa, 2015). Therefore, a surrogate is not fit to go to work immediately after the

\footnotetext{
${ }^{3}$ The Maternity Benefit (Amendment) Bill, 2016, PRS Legislative Research. Retrieved from, http://www.prsindia.org/billtrack/the-maternity-benefitamendment-bill-2016-4370/

${ }^{4}$ Please refer to footnote 3
} 


\section{Table 1: Maternity/Parental Leave Policies of Some Countries of the World}

\begin{tabular}{|c|c|c|}
\hline Countries & $\begin{array}{l}\text { Duration of Maternity/Parental } \\
\text { Leave }\end{array}$ & Wages Paid (in percentage) \\
\hline Sweden & 420 days & $80 \%$ \\
\hline United Kingdom & 52 weeks (paid for 39 weeks) & $\begin{array}{l}\text { first } 6 \text { weeks, } 90 \% \text { of average } \\
\text { weekly earnings prior to tax } \\
\text { deductions and for the next } 33 \\
\text { weeks }-90 \% \text { or } £ 139.58 \text { of } \\
\text { mean weekly earnings } \\
\text { (whichever is lower) }\end{array}$ \\
\hline Serbia & 52 weeks & $\begin{array}{l}\text { For the first } 26 \text { weeks-paid } \\
100 \% \text {; for the weeks } 27-39- \\
\text { paid } 60 \% \text {, and from weeks } 40- \\
52-\text { paid } 30 \% \text {. }\end{array}$ \\
\hline Denmark & 52 weeks & May not be with full salary \\
\hline Canada & 52 weeks & $\begin{array}{l}\text { Paid-55\% of the salary for } 17 \\
\text { weeks. In addition, } 35 \text { weeks } \\
\text { can be availed by either } \\
\text { parent, albeit wages depends } \\
\text { according to province. }\end{array}$ \\
\hline Croatia & 98 days & $100 \%$ of average earnings \\
\hline Finland & 105 days & $70 \%$ \\
\hline Greece & 119 days & $50 \%$ \\
\hline Australia & 18 weeks & $\begin{array}{l}18 \text { weeks are paid but each } \\
\text { parent can take up to } 1 \text {-year of } \\
\text { leave }\end{array}$ \\
\hline Spain & 16 weeks & $100 \%$ \\
\hline Norway & 36 to 46 weeks & $\begin{array}{l}100 \% \text { parental benefits are } \\
\text { paid for shorter duration and } \\
80 \% \text { for shorter duration. }\end{array}$ \\
\hline Italy & 5 months & $\begin{array}{l}80 \% \text { for } 5 \text {-months but an } \\
\text { additional } 6 \text {-month leave can } \\
\text { be availed with } 30 \% \text { of their } \\
\text { salary }\end{array}$ \\
\hline France & 16 weeks & $100 \%$ \\
\hline China & $98 \%$ & $\begin{array}{l}\text { Receive maternity allowance } \\
\text { in lieu of salary }\end{array}$ \\
\hline Ireland & 26 weeks & $80 \%$ \\
\hline
\end{tabular}

Sources: Maternity pay and leave, Gov.uk. Retrieved from, https://www.gov.uk/maternity-payleave/overview; Maternity Leaves Around The World: Worst And Best Countries For Paid Maternity Leave, HuffPost Living, Canada. Retrieved from,http://www.huffingtonpost.ca/2012/05/22/maternity-leaves-around-theworld_n_1536120.html; These 9 Countries Have the World's Best Maternity Leave Policies [infographic], PayScale, Retrieved from, http://www.payscale.com/career-news/2013/05/these-9 countries-have-the-worlds-best-maternity-leave-policies-infographic 


\section{DOI: http://dx.doi.org/10.20896/saci.v4i2.210}

baby is born. She should be entitled to at least three to four weeks of rest. I also argue that fathers too should be equally responsible in upbringing a baby. Granting paternity leave might probably lessen gendered "discrimination against women at the workplace ... if men too are entitled to a long childcare leave" (Ghosh, 2016). Notwithstanding, approximately 80 countries around the globe mandates paternity leave ${ }^{5}$ including our neighbouring countries (Singapore, Hong-Kong and China that provides few days of paternity leave). The bill however, fails to make provision on extending maternity leave for mothers of premature/physically challenged babies, albeit it allows work from home option.

\section{Work-from-home option}

The new bill has introduced a progressive option of allowing a new mother to work from home depending on the nature of the work assigned to her by her employer. There is of course a large discourse on the debates and the strategies of work-life balance in India (Bhattacharyya, 2009; 2013; Lahiri-Dutt and Sil, 2014; Mukhopadyay et al., 1993; Rani and Khandelwal, 1992; Shukla and Kapoor, 1990; Sarma, 2008; Singh, 2015); it is "often challenging for a career-oriented woman ... to "have it all"-career, children, marriage, and financial stability" (Bhattacharyya, 2016b: 29). There is ample evidence to suggest that most carrier-oriented married women with children and no support mechanism, quit their jobs to look after the family (Bhattacharyya, 2009; 2013; 2016) and the career ladder of the woman breaks in the middle of her life. Hence, the work-from-home is a spectacular option to fix the 'breaks of the career ladder', where the new mother will be allowed to avail this opportunity "after the period of maternity leave, for a duration that is mutually decided by the employer and the woman." ${ }^{\prime \prime}$ I argue that flexible working hours (Bhattacharyya, 2016)

\footnotetext{
${ }^{5}$ Women, Business and the Law 2016: Getting to Equal, World Bank Group, ISBN (electronic): 978-1-4648-0678-0, DOI: 10.1596/978-1-4648-0677-3

${ }^{6}$ Please refer to footnote 3
}

should have been incorporated in the bill to help new mothers to balance their work and life in a much better way. At the same time, flexible working hours and work-from-home option for new fathers should have also been included in the bill, as it remains imperative for a new father to support his wife at the critical juncture of their life. It is also worth noting that too much flexibility and leave might "undermine women's labor force participation ... [and] make women less competitive in the labor market and discourage employers from hiring [less] women of child-bearing age" (15). ${ }^{7}$ Nonetheless, it is even more progressive of the bill to incorporate childcare facilities within the vicinity of the establishments.

\section{Childcare facilities}

As stated above, the bill makes it mandatory for those "establishment[s] with 50 or more employees to provide crèche facilities within a prescribed distance", 8 where during the day, the mother would be allowed four visits to the crèche, albeit this embraces her recess interval. Importantly, the bill has introduced a provision making it compulsory for the employers to communicate a woman in writing as well as electronically at the time of her appointment about all the benefits of maternity the woman would be entitled to as and when required.

It is reckoned that work-from-home option and childcare facilities in or within a nearby distance of the establishments would not only be of great help to the working mothers but also might reduce malnutrition in children. It is saddening to note that vast majority of India's children suffer from malnourishment. The Rapid Survey on Children ${ }^{9}$ (RSOC) conducted co-jointly by the Ministry of Women and Child Development, India and UNICEF's technical support unravelled that "29.4 per cent of children (aged less than three years) to be underweight (low in weight for their age), while

\footnotetext{
${ }^{7}$ Please refer to footnote 5

${ }^{8}$ Please refer to footnote 3

${ }^{9}$ Rapid Survey on Children (RSOC), 2013-2014, Ministry of Women \& Child Development. Retrieved from, http://wcd.nic.in/acts/rapid-survey-children-rsoc-201314
} 
15 per cent were wasted (low weight for their height) and 38.7 per cent were stunted (low in height for age)" (Bhattacharyya, 2016d; Dasgupta, 2015; Ghosh, 2016). Arguably, this could cause deaths in infants and children. Although, the problem of malnutrition is highly complex requiring a clean and healthy environment with proper toilet facilities and improved sanitation (Bhattacharyya, 2014), however, continuous breastfeeding the baby for six months or more would definitely build baby's immunity and its level of nutrition (Ghosh, 2016). Of course, the mother too needs to feed herself well with nutritious diets.

Critics however argue that the bill is lopsidedit serves only a minority of employees employed in the government sectors, private and state-owned enterprises but ignores the large number of Indian women engaged in the informal or unorganised sector (with no social security or protection), who often work under hazardous and precarious conditions as daily wage earners or are self-employed. With no maternity leaves and maternity benefits, the new mothers (mired in poor economic conditions and multi-dimensional forms of poverty) are compelled to return to work, who themselves not only fail to heal properly; at the same time leave the new baby(ies) deprived of proper nourishment and care. This often leads to high maternal and infant mortalities.

\section{Conclusion}

Notwithstanding, the bill as it currently stands bear a pending status as it is yet to be passed in the Lok Sabha (the lower house or house of the people in the Bicameral-Parliament of India). The bill remains forward-looking and prowomen, despite several shortcomings. It is expected to be passed in the forthcoming (2016) winter session of the Parliament. This would definitely enlighten expectant mothers working in the organised sector, although their counterparts working in unorganised sector continue to remain deprived of such benefits. It is also expected that an ordinance would be promulgated at an earliest date inter alia increasing maternity leave from 12 weeks to 26 weeks.

\section{Acknowledgement}

I wish to acknowledge the anonymous reviewer for the valuable comments on an earlier draft of this manuscript. I also thank everyone engaged in the journal and helping me to publish the article in its current form.

\section{References}

Bhattacharyya, Rituparna (2016a). Discounted Life: The Price of Global Surrogacy in India, Gender, Place \& Culture, 1-2, DOI: 10.1080/0966369X.2016.1211585

Bhattacharyya, Rituparna (2016b). Balancing Motherhood and Career in Stem Jobs, Space and Culture, India, 3 (3), 28-31, DOI: http://dx.doi.org/10.20896/saci.v3i3.17 8

Bhattacharyya, Rituparna (2016c). Draft Surrogacy (Regulation) Bill 2016: Rhetoric or Surrogate-centric? Space and Culture, India 4(2), 9-21, DOI: http://dx.doi.org/10.20896/saci.v4i2.21 9

Bhattacharyya, Rituparna (2016d). An Account of India's under-5 Mortality Rate, International Journal of Social Work and Human Services Practice, 4(4), 82-88, DOI: 10.13189/ijrh.2016.040402

Bhattacharyya, Rituparna (2014). Good Governance and Development Mandate, Space and Culture, India, 2(1), 1-4, DOI: $10.20896 /$ saci.v2i1.65

Bhattacharyya, Rituparna (2013). Are We Empowered? Stories of Young Indian Working Women, Saarbrücken, Germany: Lap Lambert Academic Publishing, ISBN: 978-3-659-20580-4

Bhattacharyya, Rituparna (2009). Examining the Changing Status and Role of Middle Class Assamese Women: Lessons from the Lives of University Students, PhD thesis, Newcastle University, UK

Bill Summary: The Maternity Benefit (Amendment) Bill, 2016, PRS Legislative Research. Retrieved from, 
http://www.prsindia.org/uploads/medi a/Maternity\%20Benefit/Bill\%20Summar y\%20--

\%20The\%20Maternity\%20Benefit\%20\% 28Amendment\%29\%20Bill,\%202016.pdf

Bill No. XLIII of 2016: The Maternity Benefit (Amendment) Bill, 2016, PRS Legislative Research. Retrieved from, http://www.prsindia.org/uploads/medi a/Maternity\%20Benefit/Maternity\%20B enefit\%20Bill,\%202016.pdf

Dasgupta, Rajib (2015, 17 September). India's Malnutrition Shame, The Indian Express. Retrieved from, http://indianexpress.com/article/opinio $\mathrm{n} /$ columns/indias-malnutrition-shame/

Ghosh, Abantika (2016, 25 August). Rajya Sabha may have passed bill to increase maternity leave, but social change will take longer time. The Indian Express, Retrieved from, http://indianexpress.com/article/opinio n/web-edits/rajya-sabha-may-havepassed-bill-to-increase-maternity-leavebut-social-change-will-take-longer-time2972344/

Jacobs, Ben (2016, 14 September). Donald Trump Calls for Paid Maternity Leave in Childcare Plan, The Guardian. Retrieved from, https://www.theguardian.com/usnews/2016/sep/13/trump-childcareproposal-paid-maternity-leave

Lahiri-Dutt, Kuntala and Sil Pallabi (2014). Women's 'Double Day' in Middle-class Homes in Small-town India, Contemporary South Asia, 1-17, DOI: 10.1080/09584935.2014.979762

Mukhopadyay, S., Dewanji, A. and Majumder, P.P. (1993). Working Status and Anxiety Levels of Urban Educated Women in
Calcutta, International Journal of Social Psychiatry, 39 (3), 200-207

Rani, V. and Khandelwal, P. (1992). Family

Environment and Interpersonal Behaviour: A Comparative Study of Dual Career and Single Career Families, The Indian Journal of Social Work, LIII (2), 232-243

Rudrappa, Sharmila (2015). Discounted Life: The Price of Global Surrogacy in India, New York and London: New York University Press, ISBN: 978-1-47-982532-5

Sarma, Rituparna B. (2008). Marriage, Motherhood and Career Salience: Young Women in Contemporary Society of Assam. In A.K. Ray and BD Ray (eds.) Women Emancipation: Focus North East India. New Delhi: Om Publications, 163182

Shukla, Archana and Kapoor, Madhulika (1990). Sex-Role Identity, Marital Power and Marital Satisfaction among Middle Class Couples in India, Sex Roles, 22(11), 693706, DOI: 10.1007/BF00292055

Singh, Suman (2015). Are We Empowered? Stories of Young Indian Working Women, Journal Space and Culture, India, 2(4), 80-81, DOI: http://dx.doi.org/10.20896/saci.v2i4.13 1

The Maternity Benefit (Amendment) Bill, 2016, PRS Legislative Research. Retrieved from, http://www.prsindia.org/billtrack/thematernity-benefit-amendment-bill2016-4370/

The Maternity Benefit Act, 1961. Retrieved from, http://www.ilo.org/dyn/travail/docs/67 8/maternitybenefitsact1961.pdf 